\title{
The Application of Information Success Model in Perpustakaan Tun Abdul Razak (PTAR) UiTM
}

\author{
Noor Azlin Binti Abdullah ${ }^{1} \&$ Safawi Abdul Rahman ${ }^{2}$ \\ ${ }^{1}$ Perpustakaan Sultan Badlishah, Universiti Teknologi MARA Cawangan Kedah, \\ 08400 Sungai Petani Kedah \\ ${ }^{2}$ Faculty of Information Management, Universiti Teknologi MARA, \\ 40150 Shah Alam, Selangor, Malaysia \\ Corresponding author email: noorazlin@uitm.edu.my \\ DOI: https://doi.org/10.24191/aclim.v1i1.3
}

Received: 25/1/2021 / Accepted: 27/5/2021 / Published Online: 15/7/2021

\begin{abstract}
Abstrak
Teknologi Maklumat dan Komunikasi dan Internet banyak merubah cara penyampaian perkhidmatan organisasi. Dengan menggunakan teknologi ICT dan dan Internet, organisasi boleh menyampaikan perkhidmatan digital kepada pengguna dengan lebih pantas dan berkesan. Dalam konteks perpustakaan dan perpustakaan digital, penyampaian perkhidmatan telah banyak dipertingkatkan selaras dengan kepesatan penggunaan ICT dan Internet di perpustakaan. Kertas kerja ini membincangkan penyampaian perkhidmatan perpustakaan digital di Perpustakaan Tun Abdul Razak (PTAR) UiTM dengan merujuk kepada Information System Success Model yang diperkenalkan oleh Delone \& Mclane. Inisiatif digital PTAR seperti MyKnowledge Portal, CHAT WITH LIBRARIAN, E-Kelas Kemahiran Maklumat (eKKM) dibincangkan dengan memadankannya dengan elemen service quality, information quality dan system quality dalam IS Success Model. Hasilnya, dari konteks penggunaan system sebagai alat service delivery, pelaksanaan inisiatif digital PTAR adalah selaras dengan IS Success Model.
\end{abstract}

\begin{abstract}
Information and Communications Technology (ICT) and Internet have changed the way organizations deliver services. Using ICT and Internet technology, organizations can deliver digital services to consumers quickly and effectively. In the context of libraries and digital libraries, service delivery has been greatly improved along with the extensive use of ICT and Internet in the library. This paper discusses the delivery of digital library services at UiTM's Tun Abdul Razak Library (PTAR) with reference to the Information System Success Model introduced by Delone \& Mclane. PTAR digital library initiatives such as MyKnowledge Portal, CHAT WITH LIBRARIAN, E-Class Information Skills (eKKM) are discussed by mapping them with service quality (SQ), Information Quality and System Quality elements in the IS Success Model. As a result, from the context of the use of the system as a service delivery platform, the implementation of PTAR digital initiative is found to be aligned with IS Success Model.
\end{abstract}

Keywords: ICT and internet; service delivery; IS Success Model; Digital Library initiatives; Perpustakaan Tun Abdul Razak.

\subsection{Introduction}

With the advancement of ICT and Internet connection, information in digital form can be obtained from various sources, and easily and quickly accessed. With this nature of information retrieval, information and should therefore be provided in the digital platform. The library as one of information provider has no exception and this is a major library consideration where services must be provided digitally to facilitate information on access, anywhere and regardless of time.

Generally, digital library plays role in providing digital materials to users. Taking into account ICT infrastructure and digital applications, the provision of digital materials to consumers is made with reference to certain principles. One 
of the principles referred to in the provision of digital information materials is the Information System Success Model (ISSM) (McLean \& Delone 2003). The ISSM consists of service quality, information quality and system quality. The ISSM mainly aim at general and comprehensive definition of IS success that covers different perspectives of evaluating information system in an organization.

Aligned with digital library advancement, Perpustakaan Tun Abdul Razak (PTAR) UiTM as an academic library needs to provide various materials digitally. The PTAR collections that include books, thesis, journals, archive materials are best delivered in digital forms. Through the digitization initiative, PTAR provided extensive access for users internally, locally and abroad.

Researchers have researched the digital services such as electronic resources, use and acceptance of digital libraries and various literature have been extensively discussed about this digital library both in Malaysia and abroad. In discussing the electronic and digital resources systems, the models commonly referred to are Information Success Model (ISM), Technology Acceptance Model (TAM), Theory of Planned Behaviour (TPB), Unified Theory of Acceptance and Use of Technology (UTAUT) and et.

This concept paper refers to the Information System Success Model of Delone \& Mclean (2003) in discussing the digitalization initiative and delivery of such materials. In this context, this paper heavily discussed the application of service quality, information quality and also system quality as practiced in PTAR UiTM. The discussion in the following sections include the literature review, application of service, system quality and information quality in the context of UiTM's PTAR.

\subsection{Literature Review}

The library is an information delivery platform supports academic activities and development. The library is responsible for acquiring, preparing, filtering and distributing the information required by users. Therefore, in this way, there is a strategic and systematic information delivery concept in which the delivery is based on the needs of the user.

The study conducted by Kala Abdoulaye and Shaneen Majid (2000) acknowledged that academic libraries in Malaysia focused on the use of the internet for the purpose of reference services. His study indicated that respondents agreed that reference librarians need high skills in the field of computer and digitization for the purpose of helping users access information through the internet to meet the needs of users. Thus, through time change and also the needs of users, digitization requires librarians to accept and be balanced according to the development and needs of technology. Qian Zhou (2005) has stated that digital librarians have embraced activities in the work process such as selecting, acquiring, preserving, organizing and managing the digital collection. In this process, it also involves technical aspects in the construction of the digital library system. The data attribute (metadata) should also explain the whole content and in this process it should once again be stressed that digital librarians should have planning, implementing and supporting direct delivery to digital services such as information navigation, consultative and data transfer as information to users.

PTAR has also conducted various programmes including empowering digital library services in support of the needs of the university's teaching and learning. Many initiatives have been taken and improved from time to time to ensure that users continue to be with PTAR services and make use of various facilities provided by librarians with the challenges of this information explosion. The PTAR's librarians responsible in continuously ensure that organizations and society they serve receive information that is indisputable in the quality.

\subsection{Role of PTAR Librarian in Different Department}

PTAR UiTM handles activities related to the digitalization and involved librarian in each of the activities. The different departments use various systems related to daily task. Table 1 lists the departments and system related to the activities and skills needed by the librarian. 
Table 1: Departments, Systems Used and Librarian Skills at PTAR

\begin{tabular}{|c|c|c|}
\hline Department & System related & Skills/ Activities for the digitalization duties \\
\hline Acquisition & $\begin{array}{l}\text { Online Public Access Catalog (OPAC), } \\
\text { Web Based Integrated Library System } \\
\text { (WILS) }\end{array}$ & $\begin{array}{l}\text { Accessing, Cataloguing, Searching \& } \\
\text { Browsing, Data collection and storage using } \\
\text { system PTAR. }\end{array}$ \\
\hline $\begin{array}{l}\text { Institutional } \\
\text { Repository (IR) }\end{array}$ & $\begin{array}{l}\text { Online Public Access Catalog (OPAC), } \\
\text { Web Based Integrated Library System } \\
\text { (WILS), UiTM IR. }\end{array}$ & $\begin{array}{l}\text { Acquiring, Scanning, Uploading and make it } \\
\text { accessible to user }\end{array}$ \\
\hline Circulation & $\begin{array}{l}\text { Online Public Access Catalog (OPAC), } \\
\text { Web Based Integrated Library System } \\
\text { (WILS) }\end{array}$ & $\begin{array}{l}\text { Inter Library Loan, retrieving data, generating } \\
\text { data and updating data. }\end{array}$ \\
\hline $\begin{array}{l}\text { Information } \\
\text { Technology (Digital) }\end{array}$ & $\begin{array}{l}\text { Diversified Computer Controlling System } \\
\text { (DCCS) }\end{array}$ & $\begin{array}{l}\text { Web designing, Upload data, storing data, } \\
\text { accessing data from the system provided by } \\
\text { PTAR. Create new database and system for } \\
\text { library. }\end{array}$ \\
\hline $\begin{array}{l}\text { Research and } \\
\text { Reference Services/ } \\
\text { Selective } \\
\text { Dissemination of } \\
\text { Information }\end{array}$ & $\begin{array}{l}\text { Online Public Access Catalog (OPAC), } \\
\text { Web Based Integrated Library System } \\
\text { (WILS), Online database (ezaccess, } \\
\text { ebooks), eKKM, UiTM IR, MyKnowledge } \\
\text { Portal, Chat with librarian, Google meet, } \\
\text { zoom etc. (online platform) }\end{array}$ & $\begin{array}{l}\text { Online Database } \\
\text { - ebooks/ejournal } \\
\text { Literacy class } \\
\text { Thesis } \\
\text { - ethesis/thesis } \\
\text { References guide } \\
\text { - library services (searching, accessing, literate, } \\
\text { and guidance skills) }\end{array}$ \\
\hline Archival & $\begin{array}{l}\text { Online Public Access Catalog (OPAC), Web } \\
\text { Based Integrated Library System (WILS) }\end{array}$ & $\begin{array}{l}\text { Collect, upload data/resources } \\
\text { and make it available for the user. }\end{array}$ \\
\hline
\end{tabular}

In ensuring the effective information delivery, some issues need to be taken into account. The activities and duties provide the provision of a system platform for online convenience that facilitates users, the diversity of information in the user field such as target groups or special groups and service delivery i.e. service to users through the way, anytime, everywhere and how it is delivered. Among the methods of delivery, the Online Database system through the MyKnowledge Portal as well as various types of databases that provide articles related to each various field of studies. The user can access and use the articles or resources available for the process of teaching and learning purposes.

The Online Database initiative through the MyKnowledge Portal system mentioned above is assessable from the Information System Success Model introduced by Delone \& McLane (2003). According to Delone and McLean (2003), the Information Success Model described the need for success and effectiveness of information delivery from the three aspects namely the system, information and service qualities. Thus, the role of digital librarians towards the preparation, development and delivery of this information has also been seen and measured through the achievements of the department's Performance Index which also supports and contributes to UiTM's achievements. The role of librarians which refers to the competency of librarians (knowledge, know-how, skills and attitudes) in PTAR involving activities such as creating, storing, analyzing, retrieving and disseminating information in the form of text, image and sound Sreenivasulu (2000) is measurable using the Delone and McLean's (2003) Information System Success Model.

\subsection{Information System Success Model (Delone \& Mclean, 2002, 2003)}

The DeLone and McLean Information Systems (IS) Success Model as a framework and model for measuring the complex dependent variable in IS research (Delone \& McLane 2003). Originally, it was to synthesize previous 
research involving IS success into a more coherent body of knowledge and to provide guidance to future researchers (Delone \& McLane 2003). The six dimensions of success model are depicted in the following diagram.

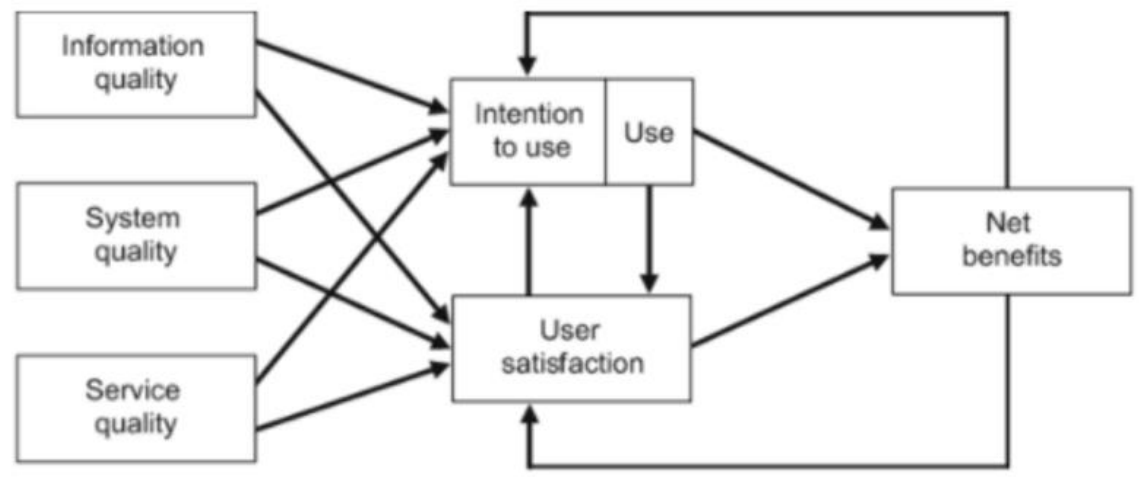

Figure 1: Information Success Model Delone \& Mclean, 2003

\subsubsection{Service Quality as of Delone \& Mclean (2003) Conception}

Quality service (SQ) as in Delone \& Mc Lean conception encompasses the relationship between usage and the desire of users to use the service. It affects the overall benefits of use for those users as well as engaging organizations and individuals with the delivery of these services. The quality of service is defined as a subjective assessment of users that the services they receive from the portal are the services they expect (Ahn et al, 2004). The quality of the service can be effectively assessed in terms of efficiency, service follow-up, empathy, confidence, reliability, and responsiveness. According to the Masrek study (2007), a strong relationship was observed between service quality and consumer satisfaction using correlation analysis. Similar evidence was found in the Lwoga (2013) and Shaltoni et al. (2015) investigations.

\subsubsection{Information Quality as of Delone \& Mclean (2003) Conception}

The Information Quality (IQ) of the Delone \& McLean's model is about the use of digital material itself. The quality criteria of the information produced must have accuracy, completeness, consistency, understanding, format, suitability according to the field or requirements of the user. To illustrate the relationship between quality of information and user satisfaction or intent to use, Lin (2007), Lwoga (2013), and Shaltoni et al. (2015) concluded that the quality of information obtained significantly affects user satisfaction and intent to use online services.

\subsubsection{System Quality as of Delone \& Mclean (2003) Conception}

System Quality (SQ) in the Delone \& McLean's conception is about the use and effectiveness of access, ease of use and availability of materials, navigation, reliability, efficiency and flexibility according to the needs of the user. However, the quality of the system also refers to the extent to which the system is 'User friendly' and can be used without specific complexity (Davis et al., 1989; Doll and Torkzadeh, 1988; See and Do., 2002).

\subsection{Discussion}

Having the brief conception about the service, information and system qualities above, this section discusses the application of Service Quality, Information Quality and System Quality in PTAR UiTM by librarians. Discussions are is established by matching each concept in the model with the intuitive and activities carried out in PTAR.

\section{The Application of System Quality di PTAR}

At PTAR, system quality is applied with each librarian to plan, build and strengthen the structure of the digital library system as well as the development of other systems that support the implementation of digitization. PTAR librarians have worked diligently to strengthen digital services through the development of several systems such as web hosting systems that provide digital services such as the MyKnowledge Management system which has details about the overall needs of users.

MyKnowledge Management service provides a platform for information search facilities such as personal information of the user itself, materials that have been borrowed or still in loan, list of information according to the requirements of the user field such as books list, ebooks, journals, institution repositories, archive materials, bank examination 
questions, articles from newspaper clippings, online databases and this has been mentioned by Bell, S.J \& Shrank, J. (2004) also support that in digitalization environment, the librarian should establish user friendly networking and set up relevant standards and policies for the digital library. The part of designing, maintain and transmit value-added information product is the important element that contribute to the success of the usage and the role of digital librarian. This is also supported by Zainab (2019) that indicated that the research on implemented system acceptance have been the focus of many previous studies including O'brien \& Marakas (2007), Venkatesh et.al. (2003), Wilson (2001) and Simon (2000) that were highly focused on retrieval, download and sharing of information.

Other related factors that had been considered in ensuring the quality of the PTAR digital system are protection of digital intellectual property in the networked environment. This consideration is to ensure the security of information and digital collections by designing the technical architecture of digital library; describing the content and attributes of items (metadata); plan, implement, and support digital services such as information navigation, consultation and transmit services; establish friendly user interface over network; set up relative standards and policies for the digital library; design, maintain and transmit add-valued information products; protect digital intellectual property in network environment; and insure information security.

It is observed that the network and system provided by PTAR play role in provide the continuous information services to user if the librarian knows the best way to choose the suitable system for their users or field. Mohamad Noorman Masrek, James Eric Gaskin (2016) mentioned that System Quality related to user satisfaction in using web digital library and its shows that systems quality significantly associated with users' satisfaction on the digital library. Due to librarian's knowledge and creative thinking, library make the decision to choose the network which highly capable to access and the system must be able to retrieve and delivering information.

\section{The Application of Service Quality di PTAR}

PTAR's quality service is established through the provision of data and information to users as well as directly through the services available. The librarians at all PTAR's branches responsible for CHAT WITH LIBRARIAN, an online service that helps users directly seeking advice and consultation from PTAR Librarian. With the use of these chats, users are able to continuously assess the efficiency and effectiveness of the delivery of information from the results of the query or the needs of those users. The digital librarian who handles CHAT WITH LIBRARIAN should have information and expertise in obtaining and meeting the needs of the users in a short time.

The librarians need some necessary knowledge and skill in handling consumers' demands and emotions thorough the chat. The quality service applies when that the librarian needs to meet the quality required by the users and to deliver the services that lead to the evaluation of the quality of the service. Each activity was evaluated according to the quality standard such as information achievement with customer satisfaction. The PTAR Reference Librarian took the initiative to provide selected materials through Selective Dissemination of Information (SDI) services i.e. obtaining materials such as journals from SCOPUS, WOS and so on. Materials need to be selected and evaluated againts good publication quality and then directly disseminated in order to assist the personnel in the University or Campus level.

It is learnt that the service quality is one of the main aspects that must be preceded in the delivery of information in order to ensure that consumers get the best service and guaranteed quality and recognized materials. Along with this, the PTAR had also intensified and introduced new teaching methods and education facilities such as online learning and research reference as indicated by (Thanuskodi, 2011).

\section{The Application of Information Quality di PTAR}

Quality information is an important aspect in ensuring that users continue to trust and believe in the digital system. As of now, PTAR librarians have managed to ensure that the information provided is quality, accessible or achievable and according to time requirements and have value in the development of the university. According to the Information Success Model of Delon \& McLean (2003), the success will affect workgroups, industries and societies (Myer et al. 1997; Seddon et al.,1999) also, there is a positive relationship between information quality and also user usage which includes the user as well as the system itself.

Among PTAR initiatives related to information quality is the implementation of online learning platform named EKelas Kemahiran Maklumat (eKKM). eKKM which is implemented online, providing 12 modules (See Figure 1) to support users in library services. The modules were implemented by all PTAR Librarians throughout Malaysia

specifically to serve the entire of UiTM's patron. As an improvement, the eKKM allow users' evaluation on the information delivery and their journey upon completion of the module. 


\begin{tabular}{|ll|}
\hline 1. & Introduction to Library Systems \\
\hline 2. & Introduction to PTAR Electronic Resources \\
\hline 3. & Online Databases \\
\hline 4. & Reference Management Software - Endnote \\
\hline 5. & Reference Management Software - Mendeley \\
\hline 6. & Advanced Literature Search I (SCOPUS: World's largest scientific database) \\
\hline 7. & Advanced Literature Search II (Identify Collaborators Using Web of Science) \\
\hline 8. & Easy Write with Microsoft Word \\
\hline 9. & Writing and Publishing \\
\hline 10. & Open Access for Scholarly Publication \\
\hline 11. & Google Scholar \& Google Drive \\
\hline 12. & PhD Clinic@PTAR \\
\hline
\end{tabular}

Figure 1: Modules in eKelas Kemahiran Maklumat (e-KKM) PTAR

There are librarians' involvement in other implementations such as MOOCS as well as video learning on how to obtain materials or access to a digital system available. This shows that PTAR librarians have had ICT competencies due to the achievement of the organizational goals that have been achieved. This also involves the delivery of comprehensive information and related information society $(\mathrm{Li}, 2007)$ and it available with the existence of such competencies. According to Mansour (2017), librarians overcome many issues related to access, organizing, value and use the information through digital literature skills and digital literature are crucial to the development of the country including Malaysia.

\subsection{CONCLUSION}

The librarians at PTAR have played a role and this discussion refers to is Delon \& McLean (2003) model as in Figure 2 below. Having looked at the development of PTAR and the achievements involving the support of universities (UiTM), it is clear that the use of PTAR Librarians has put into practice 3 key elements of is model i.e. quality service, quality system and information quatity in ensuring the continuity of service to consumers. Figure 3 shows the model for PTAR's success in digital libraries through the role of librarian. There are also a number of achievements such as the improvement of accessible materials, the continuous delivery of information in various circumstances as well as the preparation of the required materials on time. And it can be concluded here that, the competency of librarians has increased the importance of PTAR's librarian role.

\section{References:}

Bell, S.J \& Shrank, J. (2004). The Blended Librarian. A blueprint for reddening the teaching and learning role of academic librarians.

Campbell, J. D. (2006). Changing a Cultural Icon: The Academic Library as a Virtual Destination www.eric.ed.gov/ERICWebPortal/recordDetail?accno. Accessed 13/05/12.

Davis FD, Bagozzi RP and Warshaw PR (1989) User acceptance of computer technology: A comparison of two theoretical models. Management Science 35(8): 982-1003.

Doll WJ and Torkzadeh G (1988) The measurement of end-user computing satisfaction. MIS Quarterly 12(2): 259274.

Hong, W., Thong, J.Y.L., Wong, W.M. and Tam, K.Y. (2002), "Determinants of user acceptance of digital libraries: an empirical examination of individual differences and system characteristics", Journal of Management Information Systems, Vol. 18 No. 3, pp. 97-124.

Ilomäki, L., Kantosalo, A. and Lakkala, M. (2011), "What is digital competence. Linked portal”, European Schoolnet (EUN), Brussels.

K. Abdoulaye, S. Majid (2002) "Use of the Internet for reference services in Malaysian Academic libraries". Online information review vol.24, no.5. 
Li, H. (2007), "Information literacy and librarian-faculty collaboration: a model for success".

Lin HF (2007) Measuring online learning systems success: Applying the updated DeLone and McLean model. Cyberpsychology \& Behavior 10(6): 817-820

Lwoga TE (2013) Measuring the success of library 2.0 technologies in the African context: The suitability of the DeLone and McLean's model. Campus-Wide Information Systems 30(4): 288-307.

Mansour, E. (2017), "A survey of digital information literacy (DIL) among academic library and information professionals", Digital Library Perspectives, Vol. 33, pp. 166-188.

Masrek, M.N., Jamaludin, A. and Mukhtar, S.A. (2010), "Evaluating academic library portal effectiveness: a Malaysian case", Journal of Library Review, Vol. 59 No. 3, pp. 198-212.

Mohamad Noorman Masrek, James Eric Gaskin , (2016),"Assessing users satisfaction with web digital library: the case of Universiti Teknologi MARA", The International Journal of Information and Learning Technology, Vol. 33 Iss 1 pp. $36-56$.

Myers, B.L.; Kappelman, L.A.; and Prybutok, V.R. A comprehensive model for assessing the quality and productivity of the information systems function: Toward a theory for information systems assessment. In E.J. Garrity and G.L. Sanders (eds.), Information Systems Success Measurement. Hershey, PA: Idea Group, 1998, pp. 94-121.

Nwachukwu, V.N. (2005), "Computer skills competence among academic librarians: an imperative for computerization of Nigerian university libraries", A Journal of Library and Information Science, Vol. 111, pp. 97-105.

Panigyrakis, G.G. and Chatzipanagiotou, K.C. (2006), "The impact of design characteristics and support services on the effectiveness of marketing information systems: an empirical investigation", Review of Business Information Systems, Vol. 10 No. 2, pp. 91-104.

Qian, Zhou. (2005). The Development of Digital Libraries in China and the Shaping of Digtal Librarians. The Electronic Library, 23(4), p. 433-441. Accessed 12 July 2020 from: http://www.emeraldinsight.org.

Rai A, Lang SS and Welker RB (2002) Assessing the validity of IS success models: An empirical test and theoretical information analysis. Information Systems Research 13(1): 50-69.

Ramayah, T. (2006a), "Doing e-research with e-library: determinants of perceived ease of use of e-library", International Journal of Technology, Knowledge and Society, Vol. 1 No. 4, pp. 71-82.

Ramayah, T. (2006b), "Interface characteristics, perceived ease of use and intention to use an online library in Malaysia", Information Development.

Seddon, P.B.; Staples, D.S.; Patnayakuni, R.; and Bowtell, M.J. The dimensions of information systems success. Communications of the Association for Information Systems, 2, 20 (November 1999) (available at cais.isworld.org/articles/2-20/default.asp?View=pdf\&x=12\&y=13). 43.

Shaltoni AM, Khraim H, Abuhamad A, et al. (2015) Exploring students' satisfaction with universities' portals in developing countries: A cultural perspective. International Journal of Information and Learning Technology 32(2):82-93.

Thanuskodi, S. (2011), "ICT literacy among library professionals in the engineering college libraries of Tamil Nadu: an analytical study", International Journal of Digital Library Services, Vol. 1, pp. 131-141.

Venkatesh,V.;Dennis,A.R. and Ramesh,V. (2003). Adoption of collaboration technologies: Intergrating technology acceptance and collaboration technology research. Working paper on Information Systems, Vol.3, no.8:3-8.

Wilson,B. (2001) Soft System Methodology.Conceptual Modelling Building and its contribution. West Sussex:John Wiley \& Sons.

Zainab, A.M. (2019) Librarians' acceptance of open sources library information system using OSIS-UTATUT Model. Jurnal PPM: Journal of Malaysia Librarians, Vol.13, pp.13-27. 